\title{
Rancang bangun mesin pengupas tempurung kelapa
}

\author{
Budi Setiawan ${ }^{*}$, Erwin², Ari Rianto ${ }^{3}$ \\ 1,2,3Jurusan Teknik Mesin, Politeknik Negeri Sambas \\ JI. Raya Sejangkung, Sambas, Kalimanatan Barat, Indonesia \\ ${ }^{*}$ Corresponding author: setiawanbudi5379@yahoo.com
}

\begin{abstract}
The first work that must be done on coconuts after the coir stripping process is to strip the coconut shells. This is because the part of the coconut that is processed further is part of the coconut meat itself. Coconut shell is the hardest part of the coconut fruit. On this coconut shell, coconut meat is attached. Manually removing coconut meat will take a relatively long time, around 3-5 minutes for 1 coconut. Of course, with this time the capacity and production efficiency cannot be maximized. This research was conducted with the aim of designing and testing the capabilities of coconut shell peeling machines. This machine is operated by using 2 blades, namely a flat peeler blade as a barrier to the surface of the coconut shell and a toothed peeler to press the surface of the shell. The results of the functional testing of this machine obtained the best value at the rotational speed of the peeler teeth of 14 rpm with an average shelling time of 20.96 seconds per piece.
\end{abstract}

Keywords: coconut, machine, coconut shells, shelling time.

\begin{abstract}
Abstrak
Pekerjaan awal yang harus dilakukan pada buah kelapa setelah dilakukan proses pengupasan sabut adalah melakukan pengupasan tempurung kelapa. Hal ini dikarenakan bagian kelapa yang diproses lebih lanjut adalah bagian dari daging kelapa itu sendiri. Tempurung kelapa merupakan bagian yang terkeras dari buah kelapa. Pada bagian tempurung kelapa ini melekatlah daging kelapa. Pekerjaan melepas daging kelapa secara manual akan membutuhkan waktu yang relatif agak lama yaitu sekitar $3-5$ menit untuk 1 buah kelapa. Tentu saja dengan waktu tersebut kapasitas dan efisiensi produksi tidak dapat maksimal. Penelitian ini dilakukan dengan tujuan merancang dan menguji kemampuan mesin pengupas tempurung kelapa. Mesin ini dioperasikan dengan menggunakan 2 mata pisau, yaitu mata pisau pengupas berbentuk pipih sebagai penahan dari permukaan tempurung kelapa dan gigi pengupas yang berbentuk gerigi untuk menekan permukaan tempurung. Hasil pengujian fungsional dari mesin ini didapatkan nilai terbaik pada kecepatan putar gigi pengupas $14 \mathrm{rpm}$ dengan rata-rata waktu pengupasan tempurung sebesar 20,96 detik per buah.
\end{abstract}

Kata kunci: kelapa, mesin, tempurung, waktu pengupasan.

\section{Pendahuluan}

Kelapa atau nyiur (cocos nucifera), adalah tumbuhan palma pantai yang pohonnya tinggi, tanaman yang berusia cukup tua, yang banyak tersebar di seluruh daerah tropika, dan pada permulaan terik masehi sudah kenal dan dimanfaatkan orang dalam kehidupan sehari-hari dan selanjutnya telah diusahakan orang barang dagangan ke berbagai tempat, baik ke luar negeri seperti India, Sri Langka, dan ataupun di kepulauan Nusantara (Indonesia). Di Asia dan sekitar lautan Pasifik, kelapa memang sudah merupakan tanaman penting yang dikenal orang. Kemampuannya untuk berbuah pun cukup tinggi. Sebuah pohon kelapa mampu mempu menghasilkan sekitar 40-200 butir per tahun. Dari lapisan kulit yang terluar dan terdalam buah kelapa ini terdapat lapisan sabut, dan selanjutnya ada tempurung yang melapisi daging buah kelapa dan air kelapa (air buah) yang 
memiliki nilai gizi tinggi. Sementara sabutnya bisa dibuat untuk tali, karpet, dan sikat, untuk bahan bakar tungku, dan berbagai perabot rumah tangga. Dagingnya dimanfaatkan untuk santan masakan dan pembuatan minyak goreng. Bila dikeringkan, buah kelapa menjadi kopra, yakni daging buah kelapa yang sudah dikeluarkan dari tempurungnya, kemudian dikeringkan di bawah sinar matahari. Kopra inilah yang kemudian dijadikan bahan dasar untuk pembuatan minyak goreng, sabun, dan margarin. Kopra merupakan bahan ekspor penting negara kita. Sedangkan dari bunga yang mudah bisa disadap untuk pembuatan nira, cuka, arak, dan gula kelapa [1].

Langkah awal yang harus dilakukan pada pengolahan buah kelapa yaitu haruslah terlebih dahulu melakukan proses pemisahan daging kelapa dari tempurungnya. Pekerjaan ini memerlukan waktu sekitar $3-5$ menit untuk 1 buah kelapa, apabila dilakukan secara manual [2]. Jelaslah hal ini tentunya dapat menghambat laju produksi.

Guna untuk meningkatkan kapasitas produksi menuju arah yang lebih baik, perlulah dibuat sebuah mesin yang dapat memisahkan daging kelapa dari tempurungnya. Harapannya adalah dapat mempercepat kerja dan meningkat kapasitas produksi sehingga penghasilan dari para petani kelapa menjadi lebih baik.

Tujuan dari penelitian ini adalah untuk melakukan perancangan mesin pengupas tempurung kelapa dan uji kinerja dari mesin yang telah dirancang tersebut.

\section{Tinjauan Teoritis}

\section{Tempurung kelapa}

Tanaman kelapa merupakan salah satu tanaman yang paling banyak tumbuh di sepanjang garis pantai suatu daerah. Tanaman ini juga disebut sebagai tanaman serba guna, karena mulai dari daun, pelepah, buah dan batangnya dapat digunakan menjadi barang bermanfaat lainnya. Saat ini kelapa menjadi salah komoditas ekspor Indonesia. Pada tahun
2016, nilai ekspor kelapa adalah sebesar 1.123.392 ton dengan nilai sebesar 843.165.000 US Dolar [3].

Salah satu bagian terpenting dari kelapa yaitu buah kelapa. Buah kelapa ini terdiri atas beberapa bagian yaitu epicarp (kulit terluar), mesocarp (sabut), endocarp (tempurung) dan endosperm (daging buah). Bagian dari buah kelapa yang dapat dimanfaatkan menjadi bahan pangan adalah daging kelapa dan air kelapa [4].

Komposisi kimia dari tempurung kelapa adalah selulosa (34\%), hemiselulosa (21\%) dan lignin (27\%) sedangkan komposisi unsur dari tempurung kelapa adalah karbon $(74,3 \%)$, oksigen $(21,9 \%)$, silokon $(0,2 \%)$, kalium $(1,4 \%)$, sulfur $(0,5 \%)$ dan posfor $(1,7 \%)$ [5].

\section{Mesin Pemisah Tempurung Kelapa}

Penelitian mengenai mesin pemisah tempurung kelapa telah banyak dilakukan. Misalnya, penelitian tentang rancang bangun mesin pengupas tempurung kelapa. Hasil rancangan mesinnya menggunakan mata gear sebagai pendorong batok kelapa dengan mata pisau yang diletakkan pada kerangka mesin. Pengupasan tempurung kelapa dengan menggunakan mesin pengupas tersebut membutuhkan waktu rata-rata 205 detik per kelapa. Sedangkan pengupasan satu buah secara manual menghabiskan waktu sekitar 528 detik [2].

Penelitian tentang rancang bangun alat pengupas batok dan pemarut kelapa. Mesin yang dirancang tersebut menggunakan dua buah saw blade berdiameter 7 inch yang berputar dan satu buah pisau. Kecepatan maksimal dari saw blade ini adalah sebesar 46,67 rpm. Hasil percobaan yang didapatkan adalah waktu pengupasan batok kelapa rata-rata 41 detik dan kapasitas pemarutan kelapa 56,7 kg/jam [6].

Penelitian tentang rancang bangun mesin pemisah daging kelapa dari tempurung. Kelapa yang akan dikupas akan dicekam di dua sisi dengan pencekan yang masing-masing dilengkapi dengan pegas. Hasil dari rancang bangun mesin tersebut adalah mampu memisahkan daging kelapa 
selama 40 detik atau 90 buah/jam. Daya mesin yang digunakan adalah sebesar $1 / 2$ HP dan putaran $1450 \mathrm{rpm}$ [7]. Penggunaan roda gila yang diberi mata pisau untuk mencungkil tempurung kelapa.

Penelitian mengenai perancangan mesin pencungkil tempurung kelapa dengan menggunakan komponen roda gila, pisau klewang, motor penggerak, reducer, dan kerangka dudukan alat. Roda roda gila diberi mata pahat untuk pencungkil tempurung kelapa. Mata pahat ini berjumlah 64 buah dengan sudut kemiringan sebesar $26^{\circ}$. Berdasarkan hasil uji kinerja, mesin ini memiliki kapasitas rata-rata 78 kelapa dalam 10 menit, 64 kelapa dalam 30 menit, dan 663 kelapa dalam 60 menit [8].

\section{Metode Penelitian}

\section{Desain perancangan}

Berikut ditampilkan gambar desain dari perancangan mesin pengupas tempurung kelapa

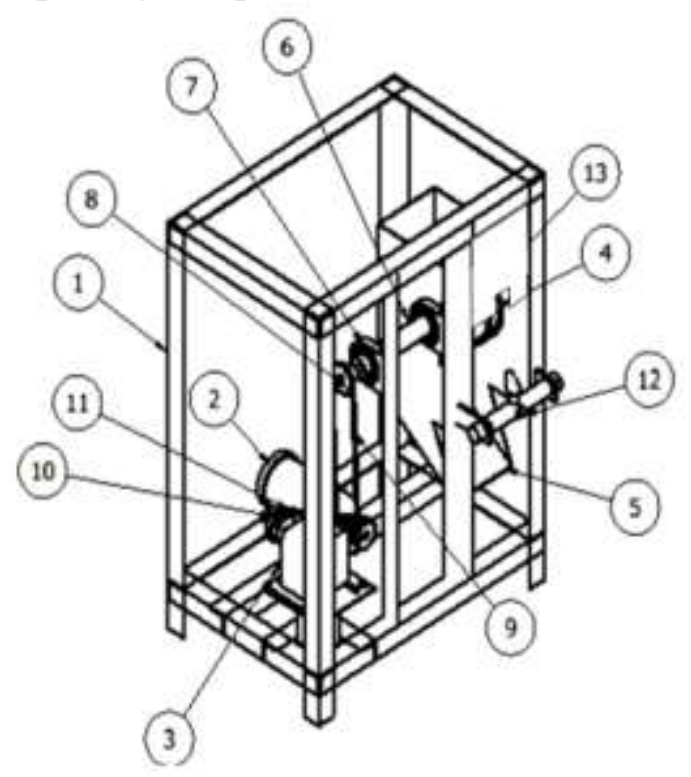

Gambar 1. Desain perancangan

Keterangan:

1. Kerangka

2. Motor listrik

3. Speed reducer

4. Pengaman gigi pengupas

5. Saluran keluar

6. Poros roda gigi

7. Roda gigi
8. Puli

9. Sabuk-V

10. Roda gigi lurus

11. Rantai

12. Poros penahan mata pengupas

13. Casing

Tahapan penelitian

Tahapan penelitian dapat dijelaskan seperti diagram alir berikut:

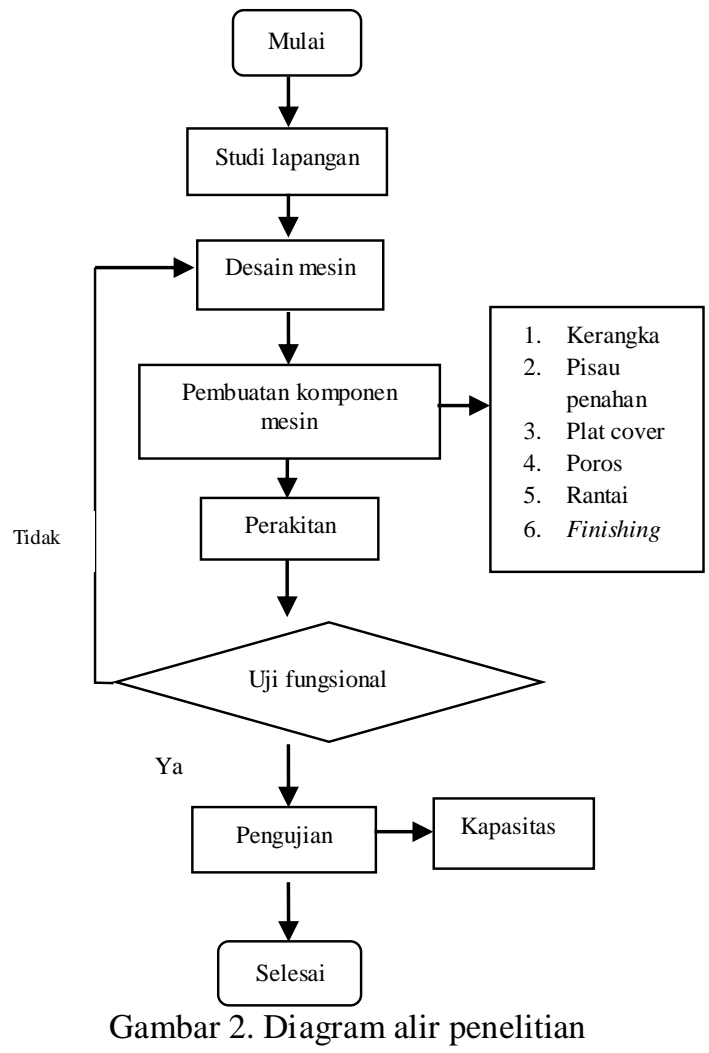

\section{Waktu dan tempat penelitian}

Penelitian ini dilakukan di Bengkel Jurusan Teknik Mesin, Politeknik Negeri Sambas pada bulan Maret 2020 - Oktober 2020.

\section{Bahan}

Bahan yang diperlukan dalam penelitian ini adalah buah kelapa.

Alat ini adalah

Alat yang digunakan pada penelitian

1. Besi siku

2. Plat

3. Motor listrik 3/4 HP

4. Stopwatch

5. Mesin las, mesin bubut dan mesin bor 
6. Puli

7. Sabuk-V

\section{Prosedur pengujian}

Dalam penelitian ini dilakukan pengujian secara sederhana yaitu menggunakan 3 perlakuan berupa kecepatan putar gigi pengupas sebesar 10,5 rpm, $14 \mathrm{rpm}$ dan 17,5 rpm. Pengujian dari mesin ini akan dilakukan sebanyak 20 kali pengulangan untuk data rata-rata mengenai kapasitas pengupasan

Prosedur pengujian dilakukan dengan langkah-langkah berikut:

1) Persiapkan kelapa yang telah dikupas sabutnya.

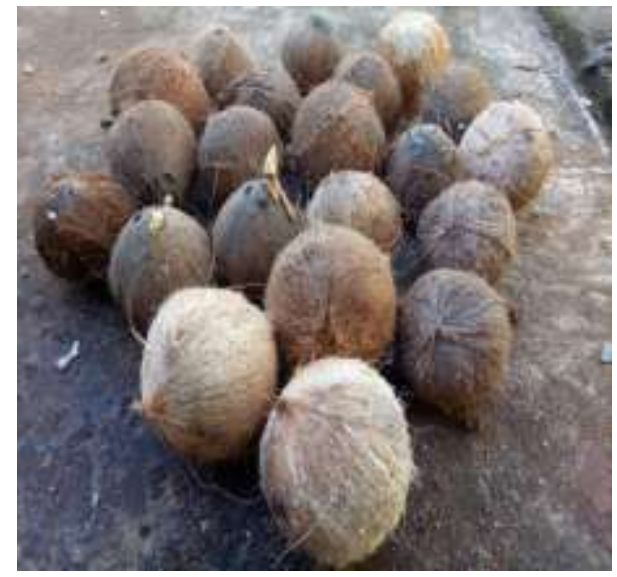

Gambar 3. Kelapa tanpa sabut

2) Melakukan proses pengupasan 1 buah tempurung kelapa dengan menggunakan mesin yang ditelah buat.

3) Melakukan pengukuran waktu yang dibutuhkan untuk proses pengupasan tempurung kelapa dengan menggunakan stopwatch.

\section{Data yang diamati}

Data yang diamati pada penelitian ini adalah waktu pengupasan. Waktu pengupasan adalah waktu yang diperlukan dalam proses pengupasan 1 buah kelapa.

\section{Hasil dan Pembahasan}

\section{Spesifikasi mesin}

Berikut ditampilkan gambar dari mesin yang telah dibuat.

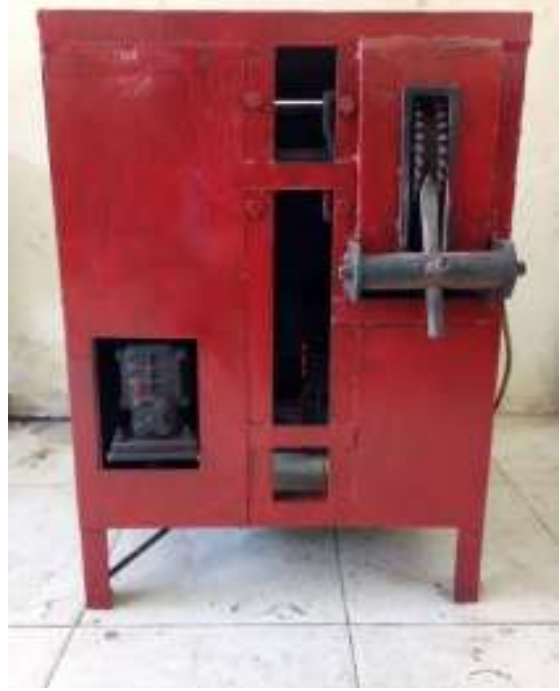

Gambar 4. Mesin pengupas tempurung kelapa

Berikut adalah data spesifikasi mesin yang telah dibuat.

Tabel 1. Spesifikasi mesin yang dibuat

\begin{tabular}{ccc}
\hline No. & Komponen & Spesifikasi \\
\hline 1 & Motor listrik & $3 / 4 \mathrm{HP}$ \\
\hline 2 & Speed reducer & $1: 50$ \\
\hline 3 & Profil gigi pengupas & Bergerigi \\
\hline 4 & Diameter poros & $30 \mathrm{~mm}$ \\
\hline 5 & Bantalan & P 207 \\
\hline 6 & Tranmisi & $\begin{array}{c}\text { Rantai dan } \\
\text { puli }\end{array}$ \\
\hline
\end{tabular}

Bentuk gigi pengupas yang digunakan pada mesin adalah adalah berbentuk gerigi dengan tingkat kelengkungan tertentu, seperti yang tampak pada Gambar 5 .

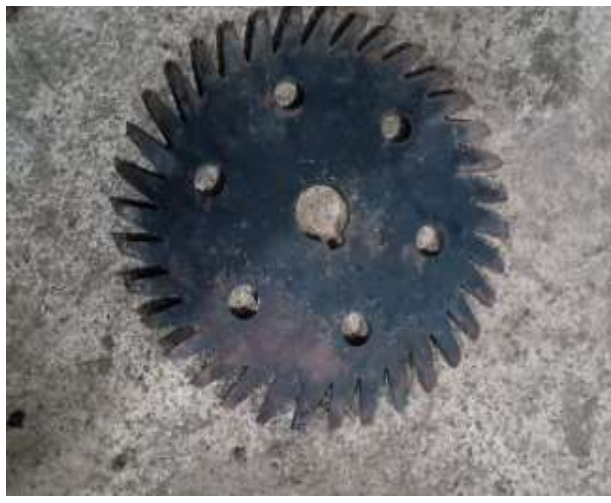

Gambar 5. Profil gigi pengupas

Gigi pengupas ini berjumlah 2 buah yang dipasangkan pada sebuah penghubung dan diperkuat dengan baut. Profil gigi dibuat agak miring dengan tujuan agar pada 
saat gigi pengupas tersebut berputar maka akan menghasilkan gaya sentrifugal [9]. Gigi pengupas inilah berfungsi untuk membuat tempurung kelapa bergerak secara rotasi sehingga langsung mengenai ujung dari mata pengupas. Akibatnya adalah lepasnya daging kelapa dari tempurung. Alasan ini juga yang menjadi dasar bahwa penggunaan gigi pengupas yang berbentuk roda gigi lurus tidak bisa digunakan karena profil giginya mempunyai bentuk cycloidal [10][11]. Berikut ditampilkan penghubung dari gigi pengupas tempurung kelapa dan mata pengupas.
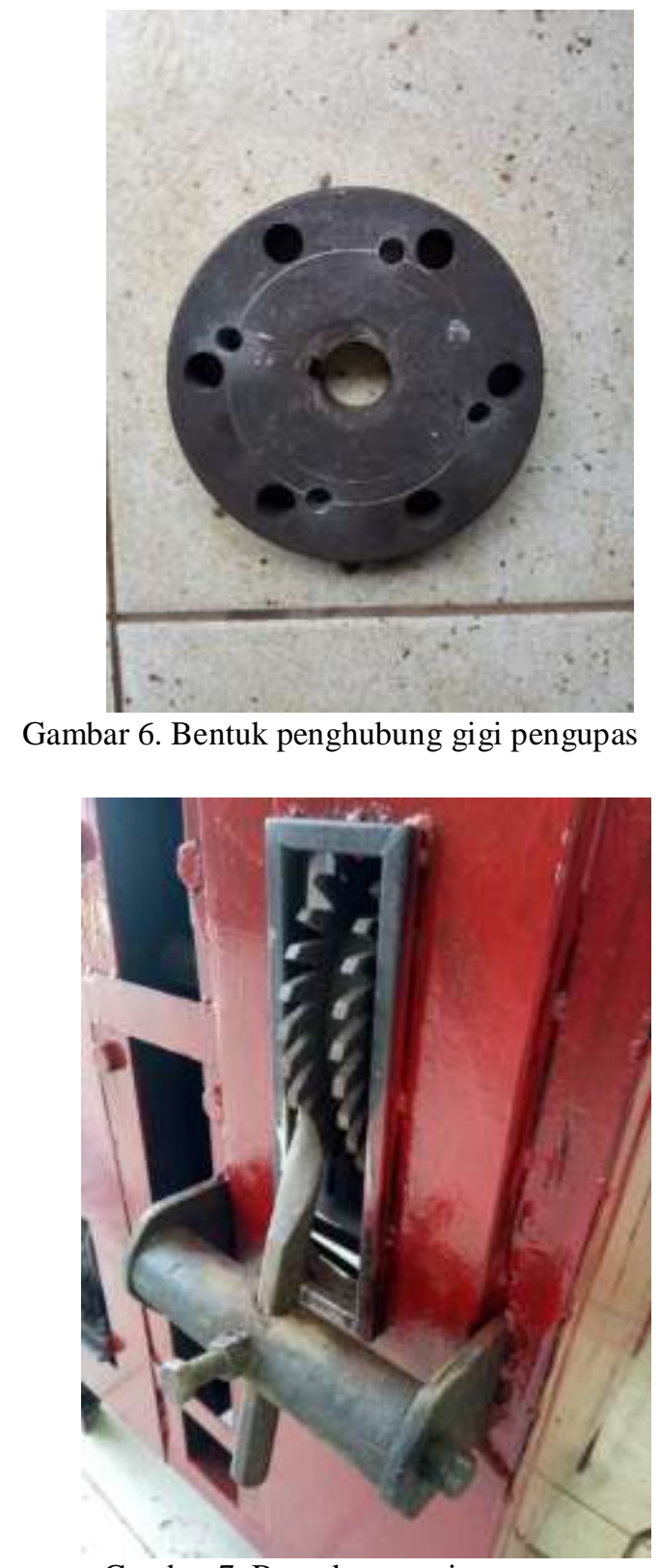

Gambar 7. Bentuk mata pisau pengupas
Mata pisau pengupas ini diletakkan pada sebuah poros dengan lubang pengatur. Mata pisau pengupas diletakkan pada lubang pengatur tersebut sehingga tinggi rendahnya tersebut bisa disesuaikan dengan kebutuhan.

Dalam mengurangi resiko kecelakaan kerja saat melakukan proses pengupasan, maka pada bidang diberi besi beton dengan ketebalan $10 \mathrm{~mm}$. Hal ini untuk mengurangi diameter kontak gigi pengupas.

\section{Cara kerja mesin}

Proses pengupasan tempurung kelapa pada mesin ini adalah didasarkan pada gerakan rotasi pada tempurung kelapa yang dihasilkan oleh gesekan antara permukaan tempurung kelapa dengan gigi pengupas. Gerak rotasi ini akan menyebabkan kontak langsung antara daging kelapa yang melekat di tempurung dengan mata pengupas sehingga menyebabkan terlepasnya daging kelapa tersebut dan proses pengupasan pun dapat terjadi.

\section{Kinerja mesin}

Hasil pengujian kinerja mesin yang telah dilakukan ditampilkan pada tabel berikut ini.

Tabel 2. Data hasil pengujian

\begin{tabular}{ccc}
\hline No. & $\begin{array}{c}\text { Kecepatan putar } \\
\text { gigi pengupas } \\
\text { (rpm) }\end{array}$ & $\begin{array}{c}\text { Rata-rata } \\
\text { waktu } \\
\text { pengupasan } \\
\text { (detik) }\end{array}$ \\
\hline 1. & 10,5 & 27,50 \\
\hline 2. & 14,0 & 20,96 \\
\hline 3. & 17,5 & 38,13 \\
\hline
\end{tabular}

Dari Tabel 2 terlihat bahwa waktu pengupasan terbaik didapatkan pada kecepatan putar gigi pengupas $14 \mathrm{rpm}$ dengan rata-rata waktu pengupasan sebesar 20,96 detik. Pada kecepatan ini proses pengupasan berjalan efektif karena gesekan yang besar terjadi pada permukaan tempurung kelapa dan gigi pengupas. Besarnya gaya gesekan ini mempermudah proses pengupasan tempurung kelapa oleh mata pisau pengupas. 


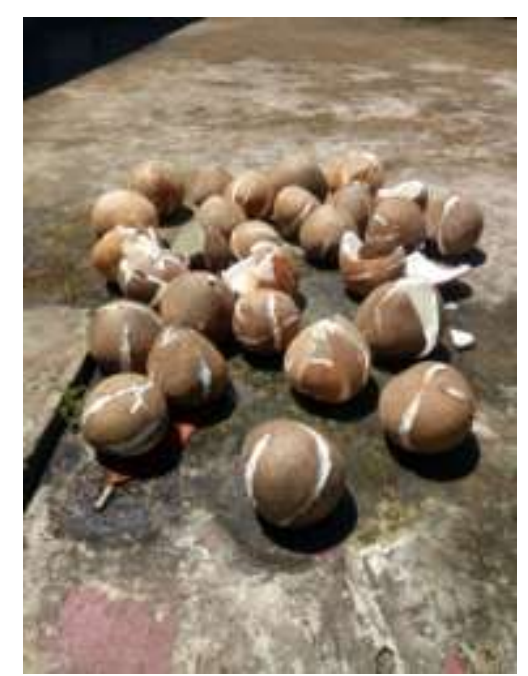

Gambar 8. Kelapa hasil pengupasan

Rata-rata waktu pengupasan terendah adalah sebesar 38,13 detik pada kecepatan putar gigi pengupas 17,5 rpm. Hal ini disebabkan karena terjadi slip yang besar antara gigi pengupas dan tempurung kelapa sehingga proses pengupasan menjadi menjadi lebih lama.

Pada kecepatan putar gigi pengupas terendah yaitu $10,5 \mathrm{rpm}$ didapatkan ratarata waktu pengupasan sebesar 27,50. Lamanya waktu pengupasan ini disebabkan oleh seringnya terjadi serpihan tempurung kelapa melekat diantara pisau pengupas dan gigi pengupas. Rendahnya kecepatan putar gigi pengupas akan menyebabkan tingginya daya tekan gigi pengupas terhadap tempurung kelapa sehingga dapat menyebabkan buah kelapa menjadi pecah.

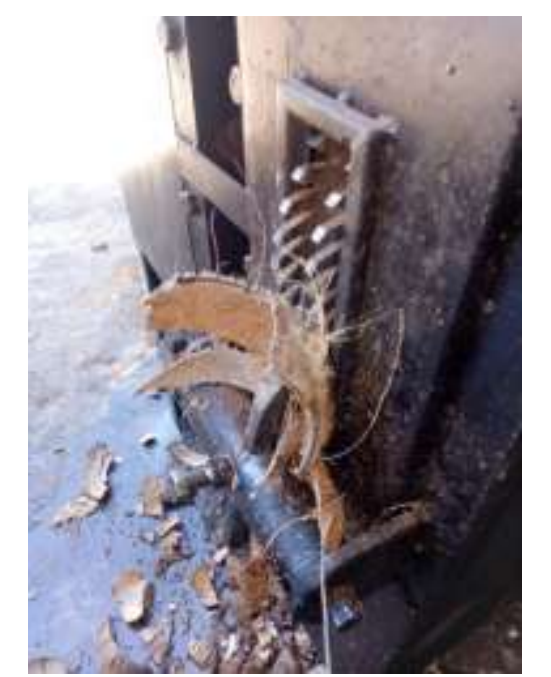

Gambar 9. Serpihan tempurung kelapa yang melekat

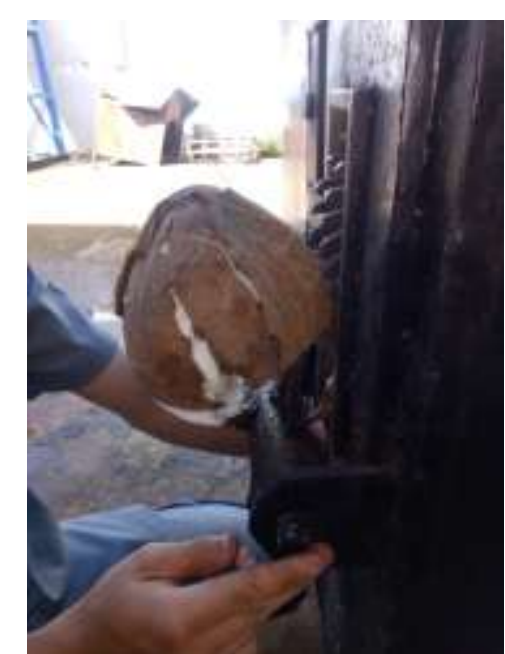

Gambar 10. Buah kelapa yang pecah saat proses pengupasan

\section{Kesimpulan}

Berdasarkan hasil pengujian yang telah dilakukan dapat disimpulkan bahwa kecepatan putar gigi pengupas $14 \mathrm{rpm}$ yang menghasilkan rata-rata waktu pengupasan terbaik yaitu 20,96 detik. Kecepatan putar yang lebih rendah akan menyebabkan sering pecahnya tempurung kelapa sehingga melekat di antara mata pengupas dan gigi pengupas. Sementara kecepatan yang lebih besar akan menyebabkan slip pada permukaan tempurung sehingga menghambat proses pengupasan.

\section{Referensi}

[1] Soekardi Y. Pemanfaatan dan Pengelahan Kelapa Menjadi Berbagai Bahan Makanan dan Obat Berbagai Penyakit. CV Yrama Widya; 2012.

[2] Prayogi G, Wahyudy R, Yogaswara S, Primayuldi T. Rancang Bangun Mesin Pengupas Tempurung Kelapa. Agroteknika. 2018;1(2):77-88.

[3] Hendaryati DD, AriantoYanuar, editors. Statistik Perkebunan Indonesia Komoditas Kelapa 2015 2017 [Internet]. Direktorat Jenderal Perkebunan; 4 p. Available from: http://ditjenbun.pertanian.go.id

[4] Purnama AS. Efek Anti-Inflamasi Liquid Smoke Tempurung Kelapa (Cocos nutrifera L.) Grade 2 pada Tikus Putih (Rattus novergicus) Galur Wistar yang Diinduksi 
Karagenan $\quad 1 \%$. Universitas

Airlangga; 2013.

[5] Bledzki AK, Mamun AA, VOLK J. Barley Husk and Coconut Shell Reinforced Polypropylene Composites: The Effect of Fibre Physical, Chemical and Surface Properties. Compos Sci Technol. 2010;70:840-6.

[6] Sholeh M, Aziz A, Santoso W, Ady BA. Rancang bangun alat pengupas batok dan pemarut kelapa. J PoliTeknologi. 2016;15(3):251-6.

[7] Supriyadi A. Rancang Bangun Mesin Pemisah Daging Kelapa Dari Tempurung. Teknoin. 2005;10(4):305-14.

[8] Tumbel N, Manurung S, Makalalag AK. Desain dan Kinerja Mesin Pencungkil Tempurung Kelapa Model Baristand Manado [Design and Performance of Coconut Desheller Machine Baristand Manado Model]. Bul Palma. 2019;20(1):27.

[9] Tipler PA. Fisika Untuk Sains dan Teknik. Jakarta: Penerbit Erlangga; 1998.

[10] Khurmi RS, Gupta JK. A Textbook of Machine Design. New Delhi: Eurasia Publishing House (PVT).LTD; 2005.

[11] Budiyanto, E., Yuono, L. D., \& Farindra, A. (2019). Upaya Peningkatan Kualitas dan Kapasitas Produksi Mesin Pengupas Kulit Kopi Kering. Turbo: Jurnal Program Studi Teknik Mesin, 8(1). 